\title{
Antitumor effect of the combination of manumycin $A$ and Immodin is associated with antiplatelet activity and increased granulocyte tumor infiltration in a $4 \mathrm{~T} 1$ breast tumor model
}

\author{
PETER SOLÁR $^{1 *}$, VERONIKA SAČKOVÁ ${ }^{1 *}$, GABRIELA HRČKOVÁ ${ }^{2}$, VLASTA DEMEČKOVÁ $^{1}$, \\ MONIKA KASSAYOVÁ ${ }^{1}$, BIANKA BOJKOVÁ ${ }^{1}$, DAGMAR MUDROŇOVÁ ${ }^{3}$, SOŇA GANCARČÍKOVÁ ${ }^{3}$, \\ RASTISLAV JENDŽELOVSKÝ ${ }^{1}$ and PETER FEDOROČKO ${ }^{1}$ \\ ${ }^{1}$ Institute of Biology and Ecology, Faculty of Science, Pavol Jozef Šafárik University in Košice, 04154 Košice; \\ ${ }^{2}$ Institute of Parasitology of Slovak Academy of Science, 04001 Košice; \\ ${ }^{3}$ University of Veterinary Medicine and Pharmacy, 04181 Košice, Slovak Republic
}

Received May 17, 2016; Accepted June 25, 2016

DOI: $10.3892 / o r .2016 .5265$

\begin{abstract}
Manumycin A is a natural antibiotic isolated from Streptomyces parvulus with broad range of biological activities including antineoplastic activity in several in vitro and in vivo cancer models. Immodin [dialyzable leukocyte extract (DLE)] is a dialysate released from disintegrated blood leukocytes of healthy donors which exerts immunonormalizing effects on cell-mediated immune responses. The aim of the present study was to explore the antitumor potential of the combination of manumycin A and Immodin in an experimental breast cancer model. Experiments were carried using a 4T1 tumor-bearing BALB/c mouse model. Survival analysis, tumor growth, hematological and biochemical profiles, leukocyte differential, phagocytic activity of leukocytes and histology of the primary tumor were examined. The combination treatment suppressed the tumor growth and prolonged the survival of tumor-bearing mice, decreased the number of monocytes, plateletes and plateletcrit in peripheral blood of the tumor-bearing mice and increased the infiltration of neutrophils and eosinophils in the primary tumor. Moreover, individual therapies enhanced the phagocytic activity of monocytes and neutrophils. These findings demonstrate the antitumor effect of the combination of manumycin A and Immodin in 4T1 tumor-bearing mice
\end{abstract}

Correspondence to: Dr Peter Solár, Institute of Biology and Ecology, Faculty of Science, Pavol Jozef Šafárik University in Košice, Šrobárova 2, 04154 Košice, Slovak Republic

E-mail: peter.solar@upjs.sk

*Contributed equally

Key words: 4T1, manumycin A, Immodin, eosinophils, neutrophils, platelet associated with strong antiplatelet activity and innate immunity activation.

\section{Introduction}

Manumycin A is a natural antibiotic isolated from Streptomyces parvulus with various biological activities that can act as a competitive Ras farnesyltransferase inhibitor or irreversible inhibitor of neutral sphingomyelinase. Manumycin A as a single agent and also in two- or triple-drug combinations showed in vitro and in vivo anticancer activity based on its cytotoxic, antiproliferative, proapoptotic, proautophagic, antiangiogenic and antimetastatic properties in various experimental models of fibrosarcoma (1), pancreatic (2) and anaplastic thyroid cancer (3), glioma (4), lymphoma (5) and others. Manumycin A has been shown to be effective against aggressive and therapy-resistant triple-negative breast cancer (6). However, in addition to its anticancer properties, manumycin A also exerts beneficial effects on atherosclerosis (7) and immunomodulatory properties including modification of pro-inflammatory responses in glioma and non-glioma tumor cells through abrogation of IL-1 $\beta$-induced HIF-1 $\alpha$ activation in tumor cells (8), suppression of interferon- $\gamma$ and tumor necrosis factor- $\alpha$ in BALB/c-mice (9) and downregulation of mRNA for IL-6, TLR-8, IL- $1 \beta$ and inhibition of IL- $1 \beta$, IL- 6 and IL- 8 production in human monocytes (10).

Immodin [also known as DLE or transfer factor (TF)] is a leukocyte immunomodulator and represents dialyzable leukocyte extracts (DLEs) released from disintegrated blood leukocytes of healthy human donors which are able to transfer cell-mediated immunity from sensitized donors to naive recipients. The benefits of $\mathrm{TF}$ were discovered $\sim 50$ years ago and the clinical experience is based on the extensive research conducted by numerous groups worldwide $(11,12)$. DLE or TF preparations have been reported as beneficial in a broad spectrum of pathologies caused by microbial agents (13; reviewed in ref. 14) and in various diseases including allergies, 
rhinitis (15), asthma and atopic dermatitis (16), also sepsis (17) and rheumatoid arthritis (18). In the context of cancer therapy, DLE was found to be effective as an adjuvant to chemotherapy in patients with osteosarcoma (19), non-small cell lung $(20,21)$ and breast cancer (22), in experimental glioma (23), and DLE improved survival in patients with bronchogenic carcinoma (24) and prostate cancer (25). In regard to cancer, the mechanisms that underlie the immunomodulatory effects of DLE have not been elucidated.

The key steps in breast tumor progression, including cellular transformation, proliferation, tumor cell survival and angiogenesis, can be mediated by components of the hemostatic system (26). Platelets as part of the circulatory system play a fundamental role in maintaining hemostasis. However, in addition to this role, they are also important factors in inflammation, atherosclerosis and cancer dissemination. Complex interactions between tumor cells and circulating platelets play an important role in cancer growth and dissemination (27). Platelets guard tumor cells from immune elimination and promote their arrest at the endothelium (28). The growing tumor can enhance the production and activation of platelets, thereby potentially creating a positive feedback loop to fuel tumor growth (29). In addition, a tumor produces high levels of cytokines and growth factors known to promote tumor growth and metastasis and these factors can be sequestered in and released by platelets (30). These pro-tumorigenic effects make platelets a rational target for anticancer therapy.

The other components of the circulatory system, neutrophils and eosinophils, are essential parts of innate immunity. However, in addition to their important role in fighting infections and inflammation, they play a critical role in the development of effective antitumor immunity (31). The infiltration of neutrophils and/or eosinophils in colorectal and primary small cell esophageal carcinoma was found to be associated with a good prognosis and enhanced survival of patients (32-34). Studies using in vivo models reported that tumor-homing neutrophils and/or eosinophils were essential for tumor rejection by initiation of changes in the tumor microenvironment (35-37).

In the present study, we used a strongly immunogenic 4T1 mouse model as a well characterized system to replicate stage IV breast cancer for evaluation of the antitumor potential of a novel combination of the natural drug manumycin A and the immunomodulator Immodin.

\section{Materials and methods}

Ethical approval. The State Veterinary and Food Administration of the Slovak Republic approved the experimental protocol (no. 4296/12-221e), and the animals were handled and sacrificed in a humane manner in accordance with the guidelines established by the relevant commission.

Reagents. Manumycin A and Immodin were purchased from Sigma-Aldrich (St. Louis, MO, USA) and IMUNA PHARM (Šarišské Michal'any, Slovakia), respectively. The drugs were freshly prepared on the day of use. Immodin was prepared by dissolving the lyophilized dialysate of $200 \times 10^{6}$ leukocytes in water for injection. Manumycin A was resuspended in vehiculum (1\% Cremophor oil in deionized water; Sigma-Aldrich) to reach the concentration of $0.5 \mathrm{mg} / \mathrm{ml}$.

Cell line. 4T1 mouse mammary carcinoma cell line was purchased from the American Type Culture Collection (ATCC; Rockville, MD, USA). Cells were maintained in RPMI-1640 medium enriched with $5 \mathrm{mM}$ glutamate and $10 \%$ heat noninactivated fetal bovine serum (FBS) (both from Thermo Fisher Scientific, Waltham, MA, USA) and maintained in a humidified incubator at $37^{\circ} \mathrm{C}$ in an atmosphere of $5 \% \mathrm{CO}_{2}$. Media were gentamicin- and antiobiotic-free.

Animal model, cancer cell inoculation and experimental design/drug treatment. Female BALB/c mice (Velaz, Prague, Czech Republic) at 10 weeks of age were used in the experiments. The animals were adapted to standard vivarium conditions with temperature $22 \pm 2^{\circ} \mathrm{C}$, relative humidity $45-60 \%$, artificial regimen (L/D 12:12 h). During the experiment, the animals were fed with a standard MP-OŠ-06 diet (Biofer, Vel'ký Šariš, Slovakia) and water ad libitum.

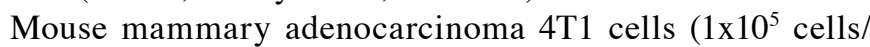
mouse) were inoculated subcutaneously in the abdominal mammary gland of syngeneic BALB/c mice on day 0 . The growth of tumors was monitored from the third day after 4T1 cell inoculation and the size of palpated tumors for each mouse individually was recorded. Animals were randomized into 6 experimental groups (25 animals/group): untreated control (C); Immodin-treated (IM); tumor control (4T1); 4T1 treated with Immodin $(4 \mathrm{~T} 1+\mathrm{IM})$; 4T1 treated with manumycin A (4T1 + MANU); 4T1 treated with Immodin and manumycin A (4T1 + IM + MANU). Drug administration was initiated on day 5 after cell inoculation corresponding to the onset of palpable tumors. Immodin was administered intraperitoneally to mice 12 times at the concentration of $0.05 \mathrm{IU} /$ mouse alone or along with manumycin A administered perorally at the dose of $100 \mu \mathrm{g} /$ mouse $(6$ times, every second day) after the onset of palpable tumors. Seventy-two hours after the final Immodin and/or manumycin A administration, 10 animals from each group were sacrificed by cervical dislocation under anesthesia. Details of the experimental scheme are shown in Fig. 1.

Tumor weight, tumor volume and animal survival. During the autopsy of $10 \mathrm{mice} / \mathrm{group}$, each primary tumor was isolated, measured and weighed on digital scales and 5 of the tumors were processed for histological analysis. The volume $(\mathrm{V})$ of tumors was calculated based on its diameters $S_{1}$ and $S_{2}\left(S_{1}<S_{2}\right)$ using the formula $V=\pi \times\left(S_{1}\right)^{2} \times S_{2} / 12$. The remaining 15 animals/group were used for the evaluation of the survival of the animals by recording the number of dead animals each day. Starting the day after analysis, the survival times of 15 animals/group were reported as the percentage of animals surviving the following 27 days. Animals in this experiment were sacrificed when moribund. On day 28, the surviving mice were euthanized by cervical dislocation. Survival data were analyzed by the program MedCalc (http:// www.medcalc.org/manual/kaplan-meier.php) as well as by GraphPad Prism software (version 5.01) (GraphPad Software, Inc., San Diego, CA, USA) and are presented in the KaplanMeier survival curves. 


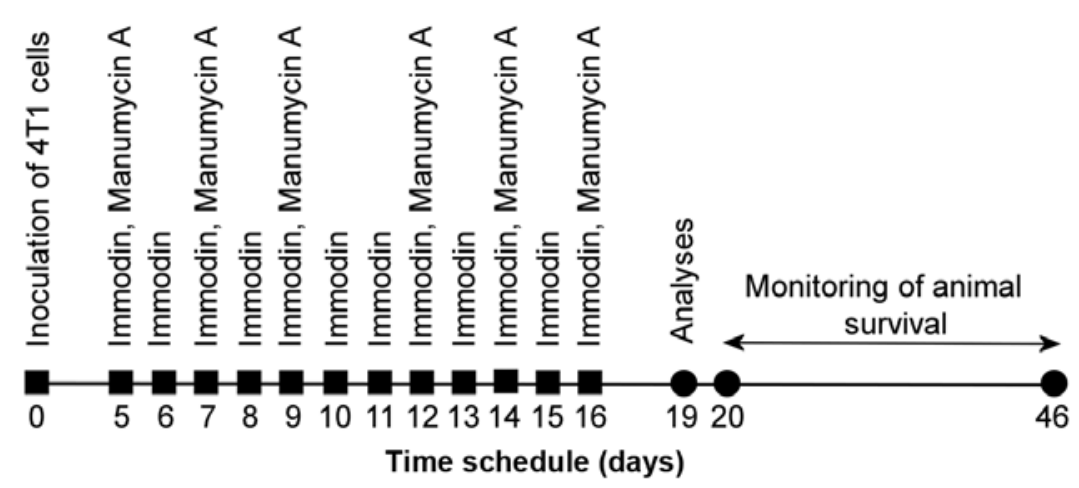

Figure 1. The experimental scheme.

Blood and serum analysis. Blood samples were collected shortly before cervical dislocation by retro-orbital bleeding in 1-ml $\mathrm{K}_{3}$ EDTA-containing tubes, 2-ml heparin-containing tubes and 2-ml serum collection tubes and stored at $4^{\circ} \mathrm{C}$. Samples with whole blood in $\mathrm{K}_{3}$ EDTA tubes (both from Sarstedt, Nümbrecht, Germany) were analyzed using an automated veterinary hematology analyzer (Mindray BC 2800VET; Mindray, Shenzhen, China). Refrigerated samples were warmed to room temperature (RT) for $30 \mathrm{~min}$ before analysis. Plasma/serum tubes were placed on ice, blood for serum collection was allowed to clot for at least $30 \mathrm{~min}$ and subsequently both tubes were centrifuged at $2,400 \mathrm{x}$ g at $4^{\circ} \mathrm{C}$ for $15 \mathrm{~min}$. Serum samples were stored at $4^{\circ} \mathrm{C}$ and biochemical analyses were performed over 2 consecutive days using an automated clinical chemistry analyzer (ELLIPSE; AMS SpA, Rome, Italy) according to the manufacturer's instructions.

Leukocyte differential count. Air-dried smears of blood were stained with May-Grünwald/Giemsa stain and scanned using a light microscope (Leica DM500; Leica, Wetzlar, Germany) at a magnification of $x 1,000$ using oil immersion following standard routines. In each microscopic field, the leukocytes were classified as lymphocytes, monocytes, eosinophils, neutrophils and basophils. In each smear, we counted 150-200 leukocytes/sample/mouse/group. The mean cell numbers were calculated after scoring smears from 10 mice/group. The neutrophil-lymphocyte ratio (NLR) was calculated from the white cell differential count.

Flow cytometric analysis of leukocyte phagocytic activity. The phagocytic activity of blood monocytes and neutrophils was quantitatively determined using a commercial test kit (FagoFlowEx kit; EXBIO, Praha, Czech Republic) which is based on the ingestion of FITC-labeled Escherichia coli (E. coli) bacteria by phagocytes. Briefly, $100 \mu 1$ of heparinized whole blood was incubated at $37^{\circ} \mathrm{C}$ for 10 min with $20 \mu \mathrm{l}$ E. coli bacteria that were opsonized with immunoglobulin and complement and fluorescein (FITC)-labeled. Control samples were incubated in an ice bath. Phagocytosis was stopped by placing the sample on ice and adding a solution that quenches the FITC fluorescence of surface bound bacteria, leaving the fluorescence of internalized particles unaltered. After two washing steps, erythrocytes were lysed by adding a BD FACS lysing solution (Becton-Dickinson Biosciences, San Jose,
CA, USA) and incubating for 20 min at RT, followed by an additional washing. A DNA staining solution was added prior to flow cytometric analysis, to exclude aggregation artefacts of bacteria or cells. Samples were kept on ice, and analyzed within 30 min of preparation using a BD FACSCanto ${ }^{\mathrm{TM}}$ flow cytometer (Becton-Dickinson Biosciences) and analyzed by BD FACSDiva $^{\mathrm{TM}}$ software. Fluorescence measurements were carried out using a $488 \mathrm{~nm}$ blue excitation laser. Bacteria were excluded using the red fluorescence histogram (FL2) where leukocytes have higher DNA content as compared to bacteria. Neutrophils and monocytes were gated separately on FSC vs. SSC dot plot and their green fluorescence histograms (FL1) were analyzed. The results are expressed as a percentage.

Histological analysis of tumor sections. Tumors isolated from 5 animals from each experimental group were fixed in $4 \%$ paraformaldehyde in phosphate-buffered saline (PBS) $\left(\mathrm{pH}\right.$ 7.2) for $24 \mathrm{~h}$ at $4^{\circ} \mathrm{C}$, washed in tap water for $5 \mathrm{~h}$ and processed for preparation of paraffin sections according to the standard protocol. Tumors were embedded in low melting paraffin (Paraplast; Sigma-Aldrich) and the sections (7- $\mu \mathrm{m}$ thick) were used for a set of staining procedures. Using the standard protocol, some slides were stained with Mayer's hematoxylin/eosin and other slides were used to localize granulocytes after modified Sirius red staining protocol originally described by Llewellyn (38). Briefly, dehydrated sections were placed in Harris hematoxylin $(\mathrm{pH} \leq 5.0)$ for $3 \mathrm{~min}$, were rinsed in running tap water and briefly immersed in $100 \%$ ethanol. This nuclear staining was followed by the staining of eosinophilic granules by alkaline Sirius red stain (without sodium chloride, $\mathrm{pH}$ 8.5) (Sigma-Aldrich), in which slides were immersed for $1 \mathrm{~h}$. After rinsing the slides in tap water for $5 \mathrm{~min}$, sections were dehydrated in a set of graded alcohols and cleared in HistoChoice clearing solution (Amresco, Solon, $\mathrm{OH}$, USA). Finally, sections were mounted into permanent medium HistoChoice mounting fluid (Amresco). After staining, granules of eosinophils were observed as bright red, whereas granules of neutrophils were not visible and both cell types could also be discriminated by the shape of nuclei stained dark blue. The morphometric analysis of both cell types was carried out at a magnification of x1,000 using Olympus Microscope BX51 and a digital analysis imaging system 'Analysis Docu' (Soft Imaging Systems 3.0; Prague, Czech Republic). After analysis of an average 30 screen fields on the sections of 
A

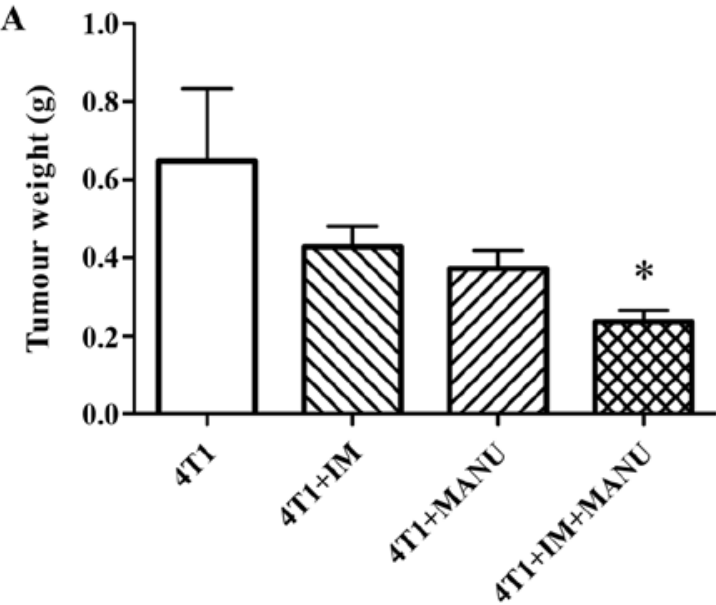

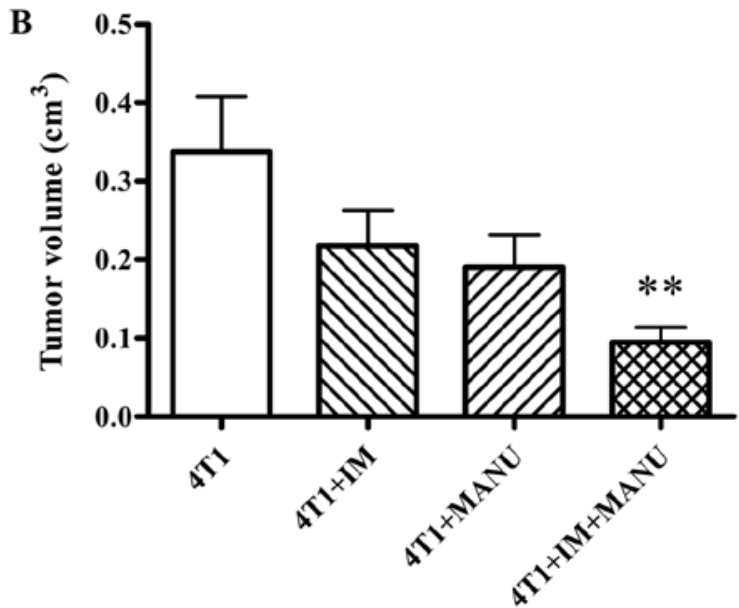

Figure 2. Effect of the treatments on (A) tumor weight and (B) tumor volume. Statistical analysis was performed using one-way ANOVA followed by Tukey's test. 4T1, tumor control (n=11); 4T1 + IM, 4T1 treated with Immodin (n=14); 4T1 + MANU, 4T1 treated with manumycin A (n=14); 4T1 + IM + MANU, 4T1 treated with Immodin and manumycin A $(\mathrm{n}=14)$. Data are expressed as mean $\pm \mathrm{SEM}\left({ }^{*} \mathrm{P}<0.05,{ }^{* *} \mathrm{P}<0.01\right.$ as compared to the $4 \mathrm{~T} 1$ group).

individual tumors the mean number of counted cells for each section was calculated for $0.1 \mathrm{~mm}^{2}$ of tissue area. Finally, the mean number of the cells recorded for the sections of tumors from 5 mice were calculated showing data for $0.1 \mathrm{~mm}^{2}$.

Statistical analyses. All results were analyzed using GraphPad Prism software (version 5.01) for normal distribution. All data were examined for normal distribution and then the appropriate tests were applied. Statistical differences between groups were analyzed using ANOVA followed by Tukey's post hoc test or ANOVA (Kruskal-Wallis test) followed by pairwise multiple comparison procedures (Dunn's method) or Mann-Whitney rank-sum test. For Kaplan-Meier survival analysis, a log-rank (Mantel-Cox) test was applied. All differences were considered statistically significant at $\mathrm{P}<0.05$. For ethical reasons, when possible and appropriate, different tissues, organs and whole blood samples from one animal were used for several measurements (i.e., samples for determination of different parameters in whole blood were obtained from the same animals).

\section{Results}

Tumor weight and tumor volume. Single agent treatments with Immodin and manumycin A resulted in a non-significant decrease in tumor weight and volume compared to the untreated 4T1 group. The combination treatment more efficiently reduced the tumor weight $(\mathrm{P}<0.01$; Fig. $2 \mathrm{~A})$ and volume $(\mathrm{P}<0.05$; Fig. 2B) compared to the untreated $4 \mathrm{~T} 1$ group.

Animal survival. Every experimental group of tumor-bearing mice had a decreased survival compared to the survival noted in the control and Immodin group $(\mathrm{P}<0.0001)$. All the treatments prolonged the survival of the tumor-bearing mice compared to that of the untreated 4T1 group $(\mathrm{P}<0.0001)$, but the most pronounced effect was observed after combined therapy. The Kaplan-Meier curves for all treatment groups showing the percentage of animals surviving vs. time are presented in Fig. 3.

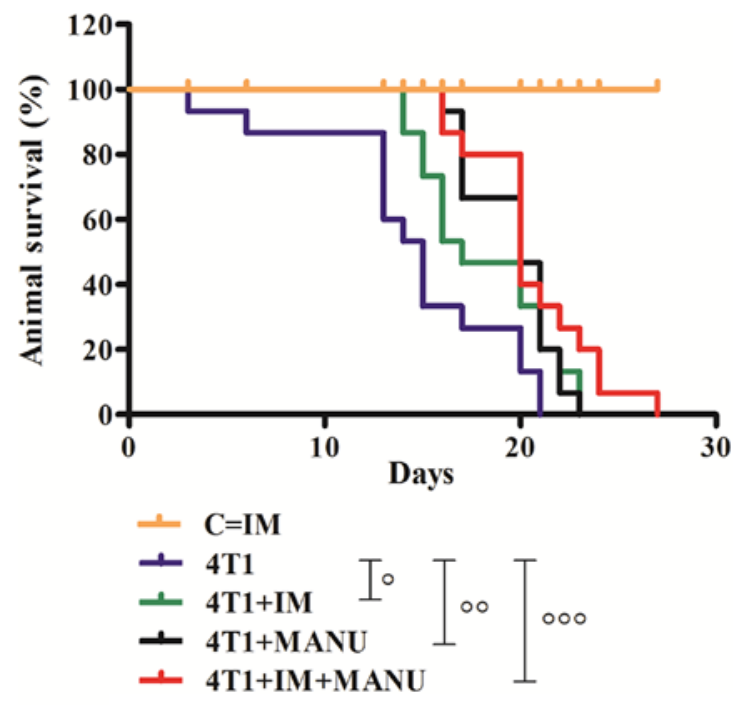

Figure 3. Effect of the treatments on animal survival. Kaplan-Meier survival curves $(\mathrm{n}=15)$ were compared using log-rank test (Mantel-Cox); $\mathrm{P}=0.0312$ (4T1 vs. $4 \mathrm{~T} 1+\mathrm{IM}$ ), $\mathrm{P}=0.0019$ (4T1 vs. $4 \mathrm{~T} 1+\mathrm{MANU}$ ), $\mathrm{P}<0.0007$ (4T1 vs. $\left.4 \mathrm{~T} 1+\mathrm{IM}+\mathrm{MANU}) ;{ }^{\circ} \mathrm{P}<0.05,{ }^{\circ} \mathrm{P}<0.01,{ }^{\circ}{ }^{\circ} \mathrm{P}<0.001\right)$. C, untreated control; IM, Immodin treatment; 4T1, tumor control; 4T1 + IM, 4T1 treated with Immodin; 4T1 + MANU, 4T1 treated with manumycin A; 4T1 + IM + MANU, 4T1 treated with Immodin and manumycin A.

Hematological parameters. The number (both the percentage and count) of monocytes was significantly increased in the untreated as well as this number in the treated 4T1 groups compared to the control $(\mathrm{P}<0.001$ for $4 \mathrm{~T} 1$ and $4 \mathrm{~T} 1+\mathrm{IM}$; $\mathrm{P}<0.01$ for $4 \mathrm{~T} 1+\mathrm{MANU} ; \mathrm{P}<0.05$ for $4 \mathrm{~T} 1+\mathrm{IM}+\mathrm{MANU})$. While the monocyte count was significantly decreased after treatment with the drug combination when compared to the count noted in the untreated 4T1 group $(\mathrm{P}<0.05)$, the percentage of monocytes was not significantly different between the untreated and treated 4T1 groups. The platelet count was significantly increased in the 4T1 group compared to that in the untreated control $(\mathrm{P}<0.05)$. The combined treatment prevented this increase; the platelet count in this group 
Table I. Effect of the treatments on hematological parameters.

\begin{tabular}{|c|c|c|c|c|c|c|}
\hline & $\mathrm{C}$ & IM & $4 \mathrm{~T} 1$ & $4 \mathrm{~T} 1+\mathrm{IM}$ & $4 \mathrm{~T} 1+\mathrm{MANU}$ & $4 \mathrm{~T} 1+\mathrm{IM}+\mathrm{MANU}$ \\
\hline Total WBCs $\left(\times 10^{9} / 1\right)$ & $6.19 \pm 0.47$ & $14.33 \pm 2.66$ & $31.34 \pm 9.37^{\mathrm{a}}$ & $43.10 \pm 6.00^{c}$ & $35.50 \pm 6.79^{\mathrm{b}}$ & $31.38 \pm 2.51^{\mathrm{b}}$ \\
\hline Monocytes (x10 $/ 1)$ & $0.17 \pm 0.03$ & $0.88 \pm 0.26$ & $2.32 \pm 0.46^{\mathrm{c}}$ & $1.85 \pm 0.19^{\mathrm{c}}$ & $1.58 \pm 0.20^{\mathrm{b}}$ & $1.13 \pm 0.08^{\mathrm{a}, \mathrm{d}}$ \\
\hline Monocytes (\%) & $2.79 \pm 0.25$ & $2.70 \pm 0.14$ & $4.92 \pm 0.34^{\mathrm{c}}$ & $4.20 \pm 0.39^{\mathrm{a}}$ & $4.14 \pm 2.6^{\mathrm{a}}$ & $4.10 \pm 0.35^{\mathrm{a}}$ \\
\hline Lymphocytes $\left(\times 10^{9} / 1\right)$ & $4.74 \pm 0.38$ & $9.23 \pm 1.71$ & $13.72 \pm 2.43^{\mathrm{b}}$ & $11.84 \pm 1.11^{\mathrm{b}}$ & $9.2 \pm 1.25$ & $10.3 \pm 0.82$ \\
\hline Lymphocytes (\%) & $76.63 \pm 2.04$ & $69.25 \pm 4.78$ & $38.00 \pm 6.47^{\mathrm{c}}$ & $29.74 \pm 2.65^{\mathrm{c}}$ & $32.63 \pm 4.62^{\mathrm{c}}$ & $34.28 \pm 0.61^{\mathrm{c}}$ \\
\hline Granulocytes $\left(\mathrm{x} 10^{9} / \mathrm{l}\right)$ & $1.3 \pm 0.16$ & $4.21 \pm 1.15$ & $22.88 \pm 8.53^{\mathrm{b}}$ & $30.23 \pm 5.14^{\mathrm{c}}$ & $24.34 \pm 5.12^{\mathrm{b}}$ & $19.50 \pm 1.62^{\mathrm{a}}$ \\
\hline Granulocytes (\%) & $20.59 \pm 1.82$ & $27.69 \pm 3.97$ & $65.10 \pm 6.90^{\mathrm{c}}$ & $71.14 \pm 3.98^{\mathrm{c}}$ & $65.97 \pm 4.67^{\mathrm{c}}$ & $60.11 \pm 1.90^{\mathrm{c}}$ \\
\hline Platelets (x109/1) & $377.0 \pm 24.25$ & $399.8 \pm 53.96$ & $631.6 \pm 73.14^{\mathrm{a}}$ & $586.2 \pm 54.22$ & $431.2 \pm 52.07$ & $321.6 \pm 42.14^{\mathrm{e}}$ \\
\hline $\operatorname{PCT}(\%)$ & $0.32 \pm 0.02$ & $0.36 \pm 0.03$ & $0.50 \pm 0.05^{\mathrm{b}}$ & $0.41 \pm 0.03$ & $0.33 \pm 0.04^{\mathrm{d}}$ & $0.23 \pm 0.03^{\mathrm{f}}$ \\
\hline PDW & $16.54 \pm 0.09$ & $16.41 \pm 0.11$ & $16.12 \pm 0.08$ & $16.14 \pm 0.09$ & $16.11 \pm 0.13$ & $16.19 \pm 0.18$ \\
\hline $\operatorname{RBC}\left(x 10^{12} / 1\right)$ & $10.78 \pm 0.23$ & $12.36 \pm 0.43$ & $13.73 \pm 0.51^{\mathrm{c}}$ & $12.69 \pm 0.4^{\mathrm{a}}$ & $12.94 \pm 0.57^{\mathrm{a}}$ & $13.04 \pm 0.40^{\mathrm{b}}$ \\
\hline $\mathrm{HCT}(\%)$ & $58.31 \pm 1.37$ & $67.81 \pm 2.40$ & $73.66 \pm 2.56^{\mathrm{a}}$ & $69.54 \pm 2.53$ & $63.90 \pm 6.17$ & $70.99 \pm 2.10$ \\
\hline $\operatorname{HGB}(\mathrm{g} / \mathrm{dl})$ & $17.49 \pm 0.46$ & $21.23 \pm 0.71^{\mathrm{a}}$ & $23.04 \pm 1.01^{\mathrm{c}}$ & $21.27 \pm 0.75^{\mathrm{a}}$ & $21.62 \pm 1.04^{\mathrm{a}}$ & $22.01 \pm 0.62^{\mathrm{b}}$ \\
\hline $\operatorname{MCV}(\mathrm{fl})$ & $54.1 \pm 0.32$ & $54.9 \pm 0.39$ & $53.70 \pm 0.26$ & $54.77 \pm 0.47$ & $53.92 \pm 0.45$ & $54.47 \pm 0.36$ \\
\hline RDW (\%) & $15.03 \pm 0.11$ & $14.97 \pm 0.15$ & $15.74 \pm 0.13^{\mathrm{a}}$ & $15.98 \pm 0.15^{\mathrm{c}}$ & $15.67 \pm 0.16^{\mathrm{a}}$ & $15.80 \pm 0.09^{b}$ \\
\hline $\operatorname{MCHC}(\mathrm{g} / \mathrm{l})$ & $299.29 \pm 1.97$ & $312.71 \pm 1.85^{\mathrm{b}}$ & $311.86 \pm 3.51^{\mathrm{b}}$ & $305.57 \pm 1.65$ & $309.71 \pm 2.24^{\mathrm{a}}$ & $309.71 \pm 1.78^{\mathrm{a}}$ \\
\hline $\mathrm{MCH}(\mathrm{pg})$ & $16.14 \pm 0.11$ & $17.13 \pm 0.11^{\mathrm{c}}$ & $16.71 \pm 0.16^{\mathrm{a}}$ & $16.67 \pm 0.09$ & $16.66 \pm 0.14$ & $16.83 \pm 0.12^{\mathrm{b}}$ \\
\hline MPV (fl) & $8.10 \pm 0.23$ & $8.03 \pm 0.19$ & $7.51 \pm 0.12$ & $7.51 \pm 0.10$ & $7.69 \pm 0.18$ & $7.76 \pm 0.15$ \\
\hline
\end{tabular}

Data are expressed as mean percentage $\pm \operatorname{SEM}(\mathrm{n}=7) ;{ }^{\mathrm{a}} \mathrm{P}<0.05$ as compared to the control; ${ }^{\mathrm{b}} \mathrm{P}<0.01$ as compared to the control; ${ }^{\mathrm{c}} \mathrm{P}<0.001$ as compared to the control; ${ }^{\mathrm{d}} \mathrm{P}<0.05$ as compared to $4 \mathrm{~T} 1 ;{ }^{\mathrm{e}} \mathrm{P}<0.01$ as compared to $4 \mathrm{~T} 1 ;{ }^{\mathrm{f}} \mathrm{P}<0.001$ as compared to $4 \mathrm{~T} 1$. C, untreated control; IM, Immodin treatment; 4T1, tumor control; 4T1 + IM, 4T1 treated with Immodin; 4T1 + MANU, 4T1 treated with manumycin A; 4T1 + IM + MANU, 4T1 treated with Immodin and manumycin A; WBC, white blood cell count; RBC, red blood cell count; HGB, hemoglobin; HCT, hematocrit; PCT, plateletcrit; $\mathrm{MCV}$, mean corpuscular volume; RDW, red cell distribution width; $\mathrm{MCHC}$, mean corpuscular hemoglobin concentration; $\mathrm{MCH}$, mean corpuscular hemoglobin; PDW, platelet distribution width; MPV, mean platelet volume.

was significantly decreased compared to the count in the untreated $4 \mathrm{~T} 1$ group $(\mathrm{P}<0.01)$ and the count reached the level similar to that of the control group. In addition, the platelet count decreased following single treatments compared to the count in the untreated 4T1 group, although these differences were not significant. There was also a significant increase in plateletcrit $(\mathrm{PCT})$ in the $4 \mathrm{~T} 1$ group compared to that in the control $(\mathrm{P}<0.01)$. Treatment with manumycin $\mathrm{A}(\mathrm{P}<0.05)$ or the drug combination $(\mathrm{P}<0.001)$ caused a decrease in plateletcrit compared to that in the untreated $4 \mathrm{~T} 1$ group. While the percentage of peripheral blood lymphocytes decreased in all $4 \mathrm{~T} 1$ groups compared to the control $(\mathrm{P}<0.001)$, the lymphocyte count was elevated in these groups compared to the count noted in the control $(\mathrm{P}<0.01)$. Comparison of the number or percentage of granulocytes and lymphocytes revealed a reversal of granulocyte-lymphocyte ratio in the tumor-bearing mice, with an 18- and 3-fold increase in the number and percentage of granulocytes. In addition, almost all hematological parameters in the 4T1 group showed a significant difference compared to the control (increase in red blood cell parameters RBC, HCT, HGB, RDW, MCHC and $\mathrm{MCH}$ ) but neither the single nor the combination treatment affected these changes (Table I).

Biochemical parameters. Analysis of biochemical parameters revealed a significant decrease in the serum concentration of total cholesterol $(\mathrm{P}<0.05)$, LDL-cholesterol $(\mathrm{P}<0.05)$, HDL-cholesterol $(\mathrm{P}<0.01)$, triglycerides $(\mathrm{P}<0.001)$ and total proteins in the untreated $4 \mathrm{~T} 1$ group compared to these values in the control $(\mathrm{P}<0.001)$. All the treatments resulted in a significant decrease in serum concentration of LDL-cholesterol compared to both the control $(\mathrm{P}<0.001$ for all treated groups) and $4 \mathrm{~T} 1$ group $(\mathrm{P}<0.05$ for $4 \mathrm{~T} 1+\mathrm{IM}$ and $4 \mathrm{~T} 1+\mathrm{MANU} ; \mathrm{P}<0.01$ for $4 \mathrm{~T} 1+\mathrm{IM}+\mathrm{MANU})$. The combined treatment prevented the decrease in serum concentration of HDL-cholesterol which was significantly increased compared to that in the $4 \mathrm{~T} 1$ group $(\mathrm{P}<0.05)$ reaching a value similar to that of the control group. The serum concentration of total proteins was increased in the 4T1 + MANU $(\mathrm{P}<0.05)$ and $4 \mathrm{~T} 1+\mathrm{IM}+\mathrm{MANU}(\mathrm{P}<0.05)$ groups compared to the serum concentration in the $4 \mathrm{~T} 1$ group (Table II). There were no significant changes in the levels of urea and creatinine or liver transaminases AST, ALP and ALT between the treated and untreated 4T1 groups (data not shown).

Leukocyte differential count. Evaluation of the white blood cell differential counts revealed a marked increase in the number of neutrophils ( $70.43 \pm 6.47$ vs. $18.00 \pm 1.88 ; \mathrm{P}<0.001)$ accompanied by a decreased number of lymphocytes $(27.71 \pm 8.06$ vs. $73.07 \pm 2.51 ; \mathrm{P}<0.001)$ and eosinophils $(0.36 \pm 0.28$ vs. $1.50 \pm 0.27 ; \mathrm{P}<0.05)$ in the $4 \mathrm{~T} 1$ group compared to these numbers in the control group. The number of monocytes was 
Table II. Effect of the treatments on biochemical parameters in serum.

\begin{tabular}{lcccccc}
\hline & $\mathrm{C}$ & $\mathrm{IM}$ & $4 \mathrm{~T} 1$ & $4 \mathrm{~T} 1+\mathrm{IM}$ & 4T1 + MANU & 4T1 + IM + MANU \\
\hline Total cholesterol (mmol/l) & $4.41 \pm 0.12$ & $4.00 \pm 0.09$ & $3.53 \pm 0.26^{\mathrm{a}}$ & $3.63 \pm 0.16^{\mathrm{a}}$ & $3.80 \pm 0.17$ & $3.90 \pm 0.10$ \\
LDL-cholesterol (mmol/l) & $2.64 \pm 0.03$ & $2.38 \pm 0.03^{\mathrm{c}}$ & $2.54 \pm 0.00^{\mathrm{a}}$ & $2.44 \pm 0.03^{\mathrm{c}, \mathrm{d}}$ & $2.44 \pm 0.02^{\mathrm{c}, \mathrm{d}}$ & $2.43 \pm 0.01^{\mathrm{c}, \mathrm{e}}$ \\
HDL-cholesterol (mmol/l) & $2.26 \pm 0.06$ & $2.15 \pm 0.08$ & $1.68 \pm 0.15^{\mathrm{b}}$ & $1.81 \pm 0.02^{\mathrm{b}}$ & $1.88 \pm 0.10$ & $2.11 \pm 0.06^{\mathrm{d}}$ \\
Triglyceride (mmol/l) & $2.99 \pm 0.00$ & $2.08 \pm 0.09^{\mathrm{c}}$ & $2.09 \pm 0.08^{\mathrm{c}}$ & $2.28 \pm 0.09^{\mathrm{c}}$ & $2.10 \pm 0.06^{\mathrm{c}}$ & $1.90 \pm 0.02^{\mathrm{c}}$ \\
Total protein $(\mathrm{g} / \mathrm{l})$ & $51.30 \pm 0.10$ & $46.90 \pm 1.10$ & $42.05 \pm 0.18^{\mathrm{c}}$ & $45.33 \pm 0.54^{\mathrm{b}}$ & $45.93 \pm 1.21^{\mathrm{b}, \mathrm{d}}$ & $46.35 \pm 0.63^{\mathrm{a}, \mathrm{d}}$ \\
\hline
\end{tabular}

Data are expressed as mean percentage $\pm \mathrm{SEM}(\mathrm{n}=7) ;{ }^{\text {a }}<0.05$ as compared to the control; ${ }^{\mathrm{b}} \mathrm{P}<0.01$ as compared to the control; ${ }^{\mathrm{c}} \mathrm{P}<0.001$ as compared to the control; ${ }^{\mathrm{d}} \mathrm{P}<0.05$ as compared to $4 \mathrm{~T} 1 ;{ }^{\mathrm{e}} \mathrm{P}<0.01$ as compared to $4 \mathrm{~T} 1$. C, untreated control; IM, Immodin treatment; 4T1, tumor control; 4T1 + IM, 4T1 treated with Immodin; 4T1 + MANU, 4T1 treated with manumycin A; 4T1 + IM + MANU, 4T1 treated with Immodin and manumycin A.

Table III. Effect of the treatments on white blood cell differential leukocyte count.

\begin{tabular}{lcccccc}
\hline & \multicolumn{1}{c}{$\mathrm{C}$} & $\mathrm{IM}$ & \multicolumn{1}{c}{$4 \mathrm{~T} 1$} & 4T1 + IM & 4T1 + MANU & 4T1 + IM + MANU \\
\hline Neutrophils (band) & $0.36 \pm 0.18$ & $0.71 \pm 0.24$ & $0.21 \pm 0.10$ & $0.14 \pm 0.09$ & $0.36 \pm 0.14$ & $0.43 \pm 0.17$ \\
Neutrophils (segment) & $18.00 \pm 1.88$ & $23.21 \pm 2.21$ & $70.43 \pm 6.47^{\mathrm{c}}$ & $75.64 \pm 3.25^{\mathrm{c}}$ & $72.43 \pm 4.86^{\mathrm{c}}$ & $68.43 \pm 2.77^{\mathrm{c}}$ \\
Lymphocytes & $73.07 \pm 2.51$ & $67.29 \pm 2.14$ & $27.71 \pm 8.06^{\mathrm{c}}$ & $16.71 \pm 2.98^{\mathrm{c}}$ & $17.57 \pm 3.82^{\mathrm{c}}$ & $22.36 \pm 2.30^{\mathrm{c}}$ \\
Eosinophils & $1.50 \pm 0.27$ & $1.21 \pm 0.26$ & $0.36 \pm 0.28^{\mathrm{a}}$ & $0.29 \pm 0.29^{\mathrm{a}}$ & $0.36 \pm 0.09^{\mathrm{a}}$ & $0.21 \pm 0.15^{\mathrm{b}}$ \\
Monocytes & $7.41 \pm 1.60$ & $7.50 \pm 0.44$ & $10.17 \pm 0.98$ & $9.25 \pm 1.16$ & $8.08 \pm 1.39$ & $9.33 \pm 1.63$
\end{tabular}

Data are expressed as mean percentage $\pm \operatorname{SEM}(\mathrm{n}=7) .{ }^{\mathrm{a}} \mathrm{P}<0.05$ as compared to the control; ${ }^{\mathrm{b}} \mathrm{P}<0.01$ as compared to the control; ${ }^{\text {}} \mathrm{P}<0.001$ as compared to the control. C, untreated control; IM, Immodin treatment; 4T1, tumor control; 4T1 + IM, 4T1 treated with Immodin; 4T1 + MANU, 4T1 treated with manumycin A; 4T1 + IM + MANU, 4T1 treated with Immodin and manumycin A.

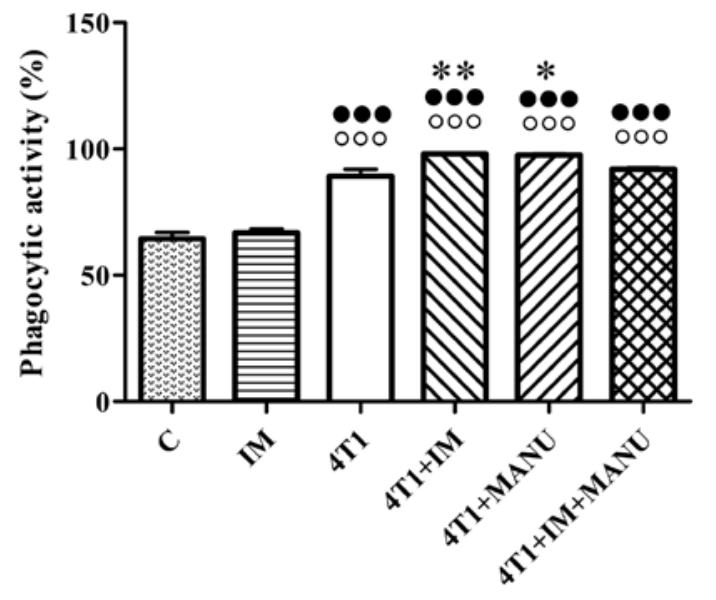

Figure 4. Total phagocytic activity of monocytes and neutrophils. Data are expressed as mean \pm SEM $(n=7) .{ }^{\circ 0} \mathrm{P}<0.001$ as compared to $\mathrm{C} ;{ }^{\cdots}{ }^{\cdots} \mathrm{P}<0.001$ as compared to IM; ${ }^{*} \mathrm{P}<0.05,{ }^{* *} \mathrm{P}<0.01$ as compared to $4 \mathrm{~T} 1$. C, untreated control; IM, Immodin treatment; 4T1, tumor control; 4T1 + IM, 4T1 treated with Immodin; 4T1 + MANU, 4T1 treated with manumycin A; 4T1 + IM + MANU, 4T1 treated with Immodin and manumycin A.

not significantly different between the tested groups. The basophile counts were $1 \pm 1$ and are not shown in Table III. The NLR calculated from the white cell differential count revealed a 14-fold increase in NLR in the 4T1 group compared to that of the control $(3.56 \pm 1.28$ vs. $0.25 \pm 0.03 ; \mathrm{P}<0.001)$. None of the therapies affected this ratio.

Phagocytic activity. Analysis of phagocytic activity of peripheral blood monocytes and neutrophils revealed a significant increase in the percentage of phagocytosing cells in all 4T1 groups compared to the controls $(\mathrm{P}<0.001)$. Administration of Immodin or manumycin A to the 4T1 group enhanced the phagocytic activity compared to the activity in the untreated 4T1 group ( $\mathrm{P}<0.01$ for IM; $\mathrm{P}<0.05$ for MANU). The phagocytic activity in the 4T1 + IM + MANU group was not significantly different from the untreated 4T1 group. Due to the same trend of phagocytic activity of monocytes and neutrophils, we decided to demonstrate the total phagocytic activity (Fig. 4).

Neutrophils and eosinophils in primary tumor tissue. Histological analysis of tumor tissue revealed an increased infiltration of neutrophils (Fig. 5A) and eosinophils (Fig. 5B) in primary tumors of the animals treated with the drug combination. The number of neutrophils was significantly higher in the 4T1 + IM + MANU group in comparison with all the other groups $(\mathrm{P}<0.05$ for $4 \mathrm{~T} 1$ and $4 \mathrm{~T} 1+\mathrm{MANU} ; \mathrm{P}<0.001$ for 4T1 + IM). The number of eosinophils was significantly higher in the 4T1 + MANU group in comparison with the 4T1 group $(\mathrm{P}<0.01)$ and in the $4 \mathrm{~T} 1+\mathrm{IM}+\mathrm{MANU}$ group in comparison with all other groups $(\mathrm{P}<0.001)$. 

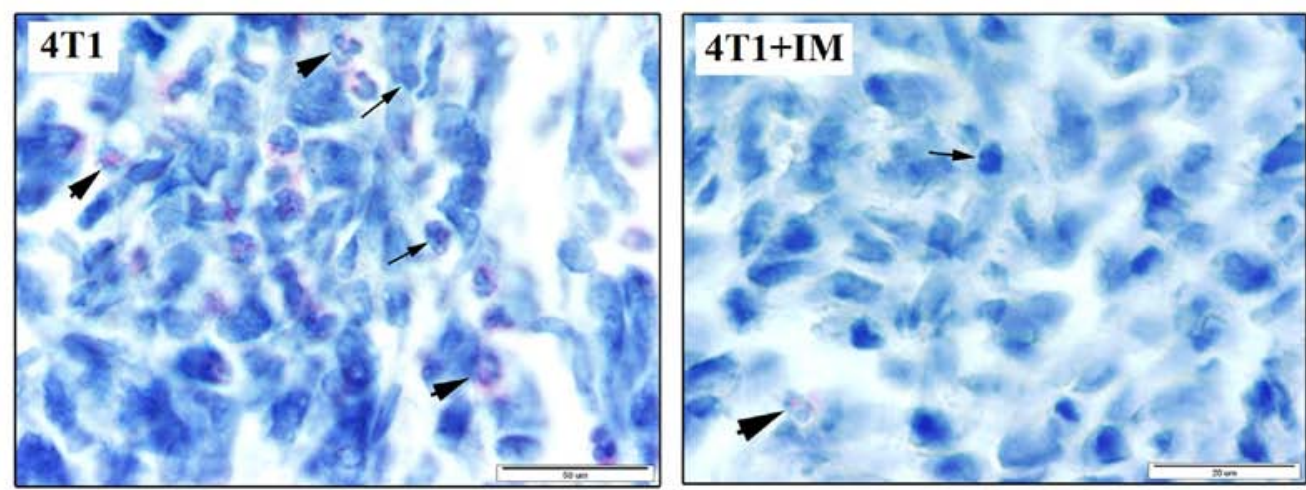

A

B
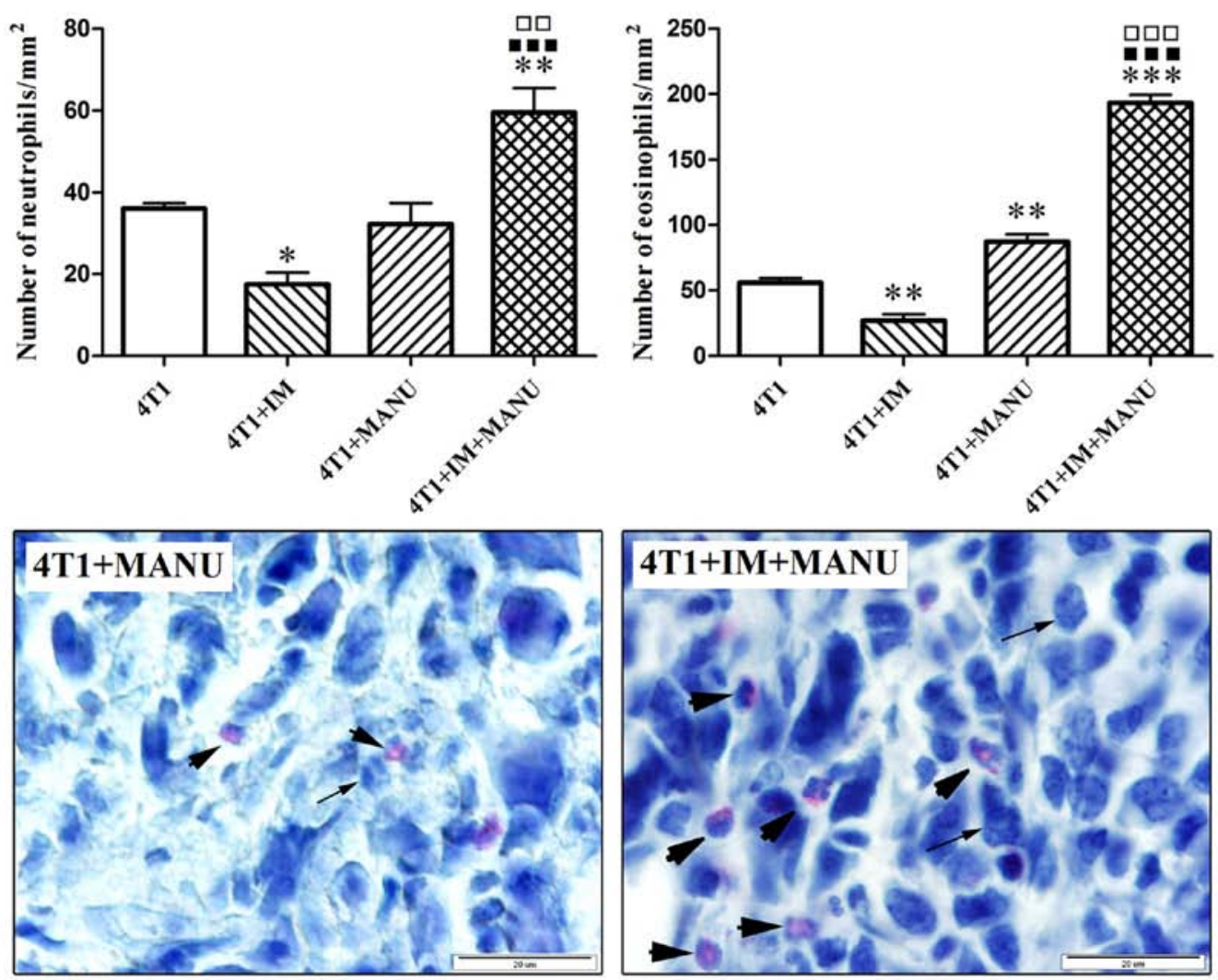

Figure 5. Effect of the treatments on the number of $(\mathrm{A})$ neutrophils and $(\mathrm{B})$ eosinophils in the primary tumor. Data are expressed as mean \pm SEM ( $=5)$. 4T1, tumor control; 4T1 + IM, 4T1 treated with Immodin; 4T1 + MANU, 4T1 treated with manumycin A; 4T1 + IM + MANU, 4T1 treated with Immodin and manumycin A. ${ }^{*} \mathrm{P}<0.05,{ }^{* *} \mathrm{P}<0.01$ as compared to $4 \mathrm{~T} 1 ;{ }^{-*} \mathrm{P}<0.001$ as compared to $4 \mathrm{~T} 1+\mathrm{IM}$; ${ }^{\square} \mathrm{P}<0.01$, ${ }^{\square} \mathrm{P}<0.001$ as compared to $4 \mathrm{~T} 1+\mathrm{MANU}$. Representative images from each group are shown. Arrows and arrowheads indicate neutrophils and eosinophils, respectively.

\section{Discussion}

In the present study, we reported on the markedly reduced tumor growth and prolonged survival of 4T1 tumor-bearing mice receiving the combination treatment of manumycin $\mathrm{A}$ and Immodin. Since cancer-associated inflammation is a key determinant of disease progression and the inflammatory response involves systemic alterations, whole blood cell analyses were carried out to reveal alterations in the hematological profile in both untreated and treated tumor-bearing mice. Our results showed that almost all hematological parameters were affected by the tumor presence. Regarding leukocytes, an elevated white blood cell count including both the number of monocytes and granulocytes as well as an increased count of lymphocytes were detected in the peripheral blood of the tumor-bearing mice (number means both the absolute count and percentage). These changes indicate 4T1 cell-triggered activation of an inflammatory response involving systemic alterations. However, besides monocytes, none of the parameters were affected by the treatments. Monocyte counts dropped significantly after the combination treatment but were still slightly higher than in the control. On the basis of our complete results showing an antitumor effect of the combination treatment, we speculated that it may be caused by the recruitment of circulating monocytes from the blood into a tumor and their differentiation into M1-like macrophages with pro-inflammatory, cytotoxic and antitumor properties (39-41).

The analysis of the white blood cell differential counts revealed that the most abundant circulating blood leukocytes 
in the 4T1-bearing mice were neutrophils. In the same cancer model, circulating neutrophil numbers continuously increased with tumor progression (42). Increasing levels of WBC and neutrophils as a result of progressive increase in extramedullary hematopoiesis in the spleen and the liver were observed by week 2 after 4T1 tumor inoculation (43). Regarding granulocytes and lymphocytes, our results are partially in agreement with a report on leukemoid reaction caused by 4T1. Whereas DuPre' and Hunter (44) observed a profound granulocytosis associated with a decrease in peripheral blood lymphocytes as the percentage of total leukocytes and constant numbers of lymphocytes in 4T1 tumor-bearing mice (by day 15 post-tumor transplant vs. by day 19 post-tumor transplant in the present study), our results demonstrated an elevated number of granulocytes associated with a strong decrease in the percentage of peripheral blood lymphocytes and elevated lymphocyte counts. Despite the fact that the lymphocyte counts were higher in tumor-bearing mice compared to the control, comparison of the number or percentage of both the granulocytes and lymphocytes revealed a reversal of the granulocyte-lymphocyte ratio $(\mathrm{G} / \mathrm{L})$ in the tumor-bearing mice. It has been reported that with the progression of cancer, the proportion of granulocytes increases in peripheral blood and the $\mathrm{G} / \mathrm{L}$ ratio is associated with tumor progression and shorter survival (45). The high levels of granulocyte colony-stimulating factor (G-CSF) protein in the serum of tumor-bearing mice suggests that this factor is responsible for the increase in granulocytes (44). Absolute lymphocyte counts can be considered a biomarker of immune status in the presence of a malignancy (46). The rapid growth observed during the first two weeks after the inoculation of tumor cells was followed by regression of growth between weeks 2 and 4 associated with necrosis and infiltration of leukocytes (43). Our findings demonstrate the increased infiltration of primary tumors with neutrophils and eosinophils. Based on the inhibitory effect of the combination treatment on tumor growth and prolonged survival of animals, we assume the antitumor potential of granulocytes which has been reported in several studies. Carretero et al (37) demonstrated an essential role of tumor-homing eosinophils in tumor eradication and survival. Antitumor effect of Virulizin ${ }^{\circledR}$ was associated with the recruitment of eosinophils into tumors (47). Tumor-infiltrating neutrophils played an essential role in establishment of antitumor immunity following PDT (48), in stimulation of an antitumor response in early-stage human lung cancer (49) and acted as potential mediators of zoledronate-induced antitumor activity (50).

Injection of the 4T1 mammary carcinoma cell line into $\mathrm{BALB} / \mathrm{c}$ mice was found to induce a large increase in peripheral blood neutrophils that correlated with tumor growth (51). Numerous pre-clinical and clinical studies have demonstrated the association between the increased number of circulating neutrophils and tumor progression (52-54). The high neutrophil-lymphocyte ratio (NLR), one of the peripheral blood-derived indicators of the systemic inflammatory response, was found to be associated with adverse survival in many solid tumors including breast cancer (55-59). Our data also showed an increased neutrophil counts accompanied by a decreased number of lymphocytes and high levels of NLR in tumor-bearing mice. Notably, despite the fact that these changes were not modified by the treatments, they were not associated with tumor progression.

The evaluation of phagocytosis as a key mechanism of the innate immune response revealed an increased phagocytic activity of peripheral blood leukocytes in all tumor-bearing mice with a profound increase in mice treated with single manumycin A or Immodin indicating the activation of phagocytic capacity of leukocytes in the presence of the tumor and its further potentiation by single treatments. It has been revealed that the phagocytic capacity of leukocytes is significantly activated in the presence of a pathological process in the organism and this activation is much more evident in cancer patients than in patients with non-malignant disorders. In contrast, surgery, chemoradiotherapy (60) and chemotherapy (61) caused a significant decrease in the phagocytosis of peripheral blood neutrophils in breast cancer and macrophages in oral cancer (62), thus interfering with the defense reactions. In this regard, it is important that none of the treatments negatively affected the phagocytic function, since it has been suggested that such therapeutical procedures must be chosen which do not interfere with the course of defense reactions (63).

Furthermore, we observed a high number of platelets and elevated plateletcrit in the untreated tumor-bearing mice. The PDW and MPV were unchanged in all experimental groups. The same alterations in platelet parameters have been documented in patients with colorectal cancer (64). Notably, both the platelet counts and plateletcrit returned to the normal range in the tumor-bearing mice treated with the combination of manumycin A and Immodin indicating its marked antiplatelet action. This is of great importance since an elevated blood platelet count correlates with poor survival and prognosis in a large variety of cancers including breast cancer (65-69). There is evidence for the positive antitumor effect of circulating platelet reduction. Lowering platelet counts in various experimental and clinical models decreased tumor lung invasion $(70,71)$, inhibited gastric and ovarian tumor growth $(72,73)$, prevented or delayed the development of hepatocellular carcinoma (74) and resulted in better survival of patients with head and neck squamous cell carcinoma (75). Stone et al (73) suggested the existence of a paracrine circuit wherein increased production of thrombopoietic cytokines in tumor and host tissue leads to paraneoplastic thrombocytosis, which fuels tumor growth. In their study anti-interleukin (IL)-6 antibody treatment significantly reduced platelet counts in tumor-bearing mice and in patients with epithelial ovarian cancer. An increased plasma IL-6 in patients with metastatic prostate carcinoma was found to be correlated with tumor burden (76). It has been reported that the presence of a tumor increases both tumor- and hostderived IL- 6 in plasma and significant amounts of IL-6 are stored in platelets (30). Recently, it has been observed that manumycin A decreased interleukin levels involved in various types of malignancies in colorectal adenocarcinoma Caco-2 cells (77) and downregulated the mRNA for IL-6 and inhibited IL- 6 production in TNF- $\alpha$ stimulated human monocytic leukemia THP-1 cells and peripheral blood monocytes (10). Based on these data, we speculated that the antiplatelet effect of single manumycin A or the combination treatment may involve the inhibition of IL-6.

In the present study, we further demonstrated that the red blood cell markers were also affected by the tumor showing 
an increase in RBC, HCT, HGB, RDW, MCHC and MCH. All of these parameters were increased in the tumor-bearing mice. We suppose that these changes which were unaffected by either treatment, may be a consequence of tumor-stimulated stress erythropoiesis in the spleen. According to a recent study, 4T1 tumor development is associated with the suppression of medullar erythropoiesis by GCS-F, whereas tumor stress promotes erythropoiesis in the spleen. The average spleen weight and splenocyte numbers started to increase one week after 4T1 tumor cell implantation (78). Our results also showed a significant increase in mean spleen weight in tumor-bearing mice which was slightly suppressed by the combination treatment (data not shown). Yilmaz et al (79) suggested that the increase in RDW is the result of complex factors, including inflammation, oxidative stress and the immune response.

Alterations in cholesterol metabolism including decreased total serum cholesterol, LDL-cholesterol, HDL-cholesterol and triglycerides have been documented as a preclinical or consequential effect of some types of cancer $(80,81)$. In contrast, an inverse relationship has been demonstrated between HDL cholesterol and cancer risk (82-84). Low HDL-cholesterol levels may simply be a reflection of chronic conditions that increase inflammation and insulin resistance, which may directly influence atherosclerosis and carcinogenesis (85). Our results showed the ability of the combination treatment to decrease LDL-cholesterol and also to restore the concentration of HDL-cholesterol and the total protein content in tumor-bearing mice indicating the positive effect of the treatment on cholesterol and protein metabolism as part of its anticancer action. These results are in accordance with the data from another study, which showed a decrease in LDL-cholesterol in quercetin-treated S-180-bearing mice, whereas the HDL-cholesterol increased compared with levels in the S-180-bearing mice (86).

In summary, our results revealed the most potent antitumor effect of the novel combination of manumycin A and Immodin in a $4 \mathrm{~T} 1$ breast carcinoma mouse model demonstrated by reduced tumor growth and prolonged survival associated with strong antiplatelet effect and enhanced granulocyte infiltration in the primary tumor indicating that various mechanisms are involved in the antitumor activity of the combination treatment.

\section{Acknowledgements}

The present study was supported by the ASFEU Project (with ITMS code no. 26220220157) supported by the operating program 'Research and Development' funded by the European Fund for Regional Development (Slovakia) (0.7), and also by the Project SK0021, co-financed through the EEA financial mechanism, the Norwegian Financial Mechanism and the State Budget of the Slovak Republic (0.3). The authors are grateful to Dr Zuzana Jendželovská, Dr Lenka Hurtuková, Jana Vargová, Barbora Fecková and Slávka Štibraná for assistance with the technical procedures.

\section{References}

1. Hara M, Akasaka K, Akinaga S, Okabe M, Nakano H, Gomez R, Wood D, Uh M and Tamanoi F: Identification of Ras farnesyltransferase inhibitors by microbial screening. Proc Natl Acad Sci USA 90: 2281-2285, 1993.
2. Ito T, Kawata S, Tamura S, Igura T, Nagase T, Miyagawa JI, Yamazaki E, Ishiguro $\mathrm{H}$ and Matasuzawa Y: Suppression of human pancreatic cancer growth in BALB/c nude mice by manumycin, a farnesyl:protein transferase inhibitor. Jpn J Cancer Res 87: 113-116, 1996.

3. She M and Jim Yeung SC: Combining a matrix metalloproteinase inhibitor, a farnesyltransferase inhibitor, and a taxane improves survival in an anaplastic thyroid cancer model. Cancer Lett 238: 197-201, 2006.

4. Dixit D, Sharma V, Ghosh S, Koul N, Mishra PK and Sen E: Manumycin inhibits STAT3, telomerase activity, and growth of glioma cells by elevating intracellular reactive oxygen species generation. Free Radic Biol Med 47: 364-374, 2009.

5. Sears KT, Daino H and Carey GB: Reactive oxygen speciesdependent destruction of MEK and Akt in Manumycin stimulated death of lymphoid tumor and myeloma cell lines. Int J Cancer 122: 1496-1505, 2008.

6. Singha PK, Pandeswara S, Venkatachalam MA and Saikumar P: Manumycin A inhibits triple-negative breast cancer growth through LC3-mediated cytoplasmic vacuolation death. Cell Death Dis 4: e457, 2013.

7. Sugita M, Sugita $\mathrm{H}$ and Kaneki M: Farnesyltransferase inhibitor, Manumycin A, prevents atherosclerosis development and reduces oxidative stress in apolipoprotein E-deficient mice. Arterioscler Thromb Vasc Biol 27: 1390-1395, 2007.

8. Sharma V, Shaheen SS, Dixit D and Sen E: Farnesyltransferase inhibitor manumycin targets IL1 $\beta$-Ras-HIF-1 $\alpha$ axis in tumor cells of diverse origin. Inflammation 35: 516-519, 2012.

9. Saha B and Nandi D: Farnesyltransferase inhibitors reduce Ras activation and ameliorate acetaminophen-induced liver injury in mice. Hepatology 50: 1547-1557, 2009.

10. Cecrdlova E, Petrickova K, Kolesar L, Petricek M, Sekerkova A, Svachova V and Striz I: Manumycin A downregulates release of proinflammatory cytokines from TNF alpha stimulated human monocytes. Immunol Lett 169: 8-14, 2016.

11. Berrón-Pérez R, Chávez-Sánchez R, Estrada-García I, Espinosa-Padilla S, Cortez-Gómez R, Serrano-Miranda E, Ondarza-Aguilera R, Pérez-Tapia M, Pineda Olvera B, Jiménez-Martínez Mdel C, et al: Indications, usage, and dosage of the transfer factor. Rev Alerg Mex 54: 134-139, 2007.

12. Arnaudov A and Kostova Z: Dialysable leukocyte extracts in immunotherapy. Biotechnol Biotechnol Equip 29: 1017-1023, 2015.

13. Cherenko SO, Reva OA, Rekalova OM, Kibizova NI, Yasir SG and Matvienko YO: Immunotherapy with leukocyte immunomodulator dialysate in patients with multidrug-resistant tuberculosis. Asthma and Allergies 3: 13-20, 2013.

14. Viza D, Fudenberg HH, Palareti A, Ablashi D, De Vinci C and Pizza G: Transfer factor: An overlooked potential for the prevention and treatment of infectious diseases. Folia Biol 59: 53-67, 2013.

15. Homberg TA, Lara RI, Pérez-Tapia SM and Jiménez Martínez MDC: Dialyzable leukocyte extracts as adjuvant treatment for allergic rhinitis. World Allergy Organ J 7 (Suppl 1): P5, 2014.

16. Gómez Vera J, Chávez Sánchez R, Flores Sandoval G, Orea Solano M, López Tiro JJ, Santiago Santos AD, Espinosa Padilla S, Espinosa Rosales F, Huerta J, Ortega Martell JA, et al: Transfer factor and allergy. Rev Alerg Mex 57: 208-214, 2010.

17. Lokaj J, Pekarek J and Kuklinek P: Leukocyte Dialysates and Transfer Factor. Mayer V and Borvác J (eds). Slovak Academy of Science, Bratislava, pp516-525, 1987.

18. Georgescu C: Effect of long-term therapy with transfer factor in rheumatoid arthritis. Med Interne 23: 135-140, 1985.

19. Juarez PC: Effect of Transferon as an adjuvant in the treatment of osteosarcoma (In Spanish) (unpublished dissertation). National Polytechnic Institute, Mexico City, 2011.

20. Pilotti V, Mastrorilli M, Pizza G, De Vinci C, Busutti L, Palareti A, Gozzetti G and Cavallari A: Transfer factor as an adjuvant to non-small cell lung cancer (NSCLC) therapy. Biotherapy 9: 117-121, 1996.

21. Franco-Molina MA, Mendoza-Gamboa E, Zapata-Benavides P, Vera-García ME, Castillo-Tello P, García de la Fuente A, Mendoza RD, Garza RG, Támez-Guerra RS and RodríguezPadilla C: IMMUNEPOTENT CRP (bovine dialyzable leukocyte extract) adjuvant immunotherapy: A phase I study in non-small cell lung cancer patients. Cytotherapy 10: 490-496, 2008. 
22. Lara HH, Turrent LI, Garza-Treviño EN, Tamez-Guerra R and Rodriguez-Padilla C: Clinical and immunological assessment in breast cancer patients receiving anticancer therapy and bovine dialyzable leukocyte extract as an adjuvant. Exp Ther Med 1: 425-431, 2010.

23. Pineda B, Estrada-Parra S, Pedraza-Medina B, RodriguezRopon A, Pérez R and Arrieta O: Interstitial transfer factor as adjuvant immunotherapy for experimental glioma. J Exp Clin Cancer Res 24: 575-583, 2005.

24. Whyte RI, Schork MA, Sloan H, Orringer MB and Kirsh MM: Adjuvant treatment using transfer factor for bronchogenic carcinoma: Long-term follow-up. Ann Thorac Surg 53: 391-396, 1992.

25. Pizza G, De Vinci C, Cuzzocrea D, Menniti D, Aiello E, Maver P, Corrado G, Romagnoli P, Dragoni E, LoConte G, et al: A preliminary report on the use of transfer factor for treating stage D3 hormone-unresponsive metastatic prostate cancer. Biotherapy 9 123-132, 1996.

26. Lal I, Dittus K and Holmes CE: Platelets, coagulation and fibrinolysis in breast cancer progression. Breast Cancer Res 15: 207 2013.

27. Bambace NM and Holmes CE: The platelet contribution to cancer progression. J Thromb Haemost 9: 237-249, 2011.

28. Gay LJ and Felding-Habermann B: Contribution of platelets to tumour metastasis. Nat Rev Cancer 11: 123-134, 2011.

29. Lin RJ, Afshar-Kharghan V and Schafer AI: Paraneoplastic thrombocytosis: The secrets of tumor self-promotion. Blood 124: 184-187, 2014.

30. Kerr BA, Miocinovic R, Smith AK, Klein EA and Byzova TV: Comparison of tumor and microenvironment secretomes in plasma and in platelets during prostate cancer growth in a xenograft model. Neoplasia 12: 388-396, 2010.

31. Ostberg JR, Ertel BR and Lanphere JA: An important role for granulocytes in the thermal regulation of colon tumor growth Immunol Invest 34: 259-272, 2005.

32. Fernández-Aceñero MJ, Galindo-Gallego $\mathrm{M}$, Sanz J and Aljama A: Prognostic influence of tumor-associated eosinophilic infiltrate in colorectal carcinoma. Cancer 88: 1544-1548, 2000.

33. Klintrup K, Mäkinen JM, Kauppila S, Väre PO, Melkko J, Tuominen H, Tuppurainen K, Mäkelä J, Karttunen TJ and Mäkinen MJ: Inflammation and prognosis in colorectal cancer. Eur J Cancer 41: 2645-2654, 2005

34. Zhang Y, Ren H, Wang L, Ning Z, Zhuang Y, Gan J, Chen S, Zhou D, Zhu H, Tan D, et al: Clinical impact of tumor-infiltrating inflammatory cells in primary small cell esophageal carcinoma. Int J Mol Sci 15: 9718-9734, 2014.

35. Tepper RI, Coffman RL and Leder P: An eosinophil-dependent mechanism for the antitumor effect of interleukin-4. Science 257: 548-551, 1992

36. Giovarelli M, Cappello P, Forni G, Salcedo T, Moore PA, LeFleur DW, Nardelli B, Di Carlo E, Lollini PL, Ruben S, et al: Tumor rejection and immune memory elicited by locally released LEC chemokine are associated with an impressive recruitmen of APCs, lymphocytes, and granulocytes. J Immunol 164: 3200-3206, 2000.

37. Carretero R, Sektioglu IM, Garbi N, Salgado OC, Beckhove P and Hämmerling GJ: Eosinophils orchestrate cancer rejection by normalizing tumor vessels and enhancing infiltration of $\mathrm{CD} 8^{+} \mathrm{T}$ cells. Nat Immunol 16: 609-617, 2015.

38. Llewellyn BD: An improved Sirius red method for amyloid. J Med Lab Technol 27: 308-309, 1970.

39. Ma J, Liu L, Che G, Yu N, Dai F and You Z: The M1 form of tumor-associated macrophages in non-small cell lung cancer is positively associated with survival time. BMC Cancer 10: 112 , 2010.

40. Pommier A, Audemard A, Durand A, Lengagne R, Delpoux A, Martin B, Douguet L, Le Campion A, Kato M, Avril MF, et al: Inflammatory monocytes are potent antitumor effectors controlled by regulatory CD4 ${ }^{+} \mathrm{T}$ cells. Proc Natl Acad Sci USA 110: 13085-13090, 2013.

41. Chanmee T, Ontong P, Konno K and Itano N: Tumor-associated macrophages as major players in the tumor microenvironment Cancers 6: 1670-1690, 2014

42. Sagiv JY, Michaeli J, Assi S, Mishalian I, Kisos H, Levy L, Damti P, Lumbroso D, Polyansky L, Sionov RV, et al: Phenotypic diversity and plasticity in circulating neutrophil subpopulations in cancer. Cell Reports 10: 562-573, 2015

43. Tao K, Fang M, Alroy J and Sahagian GG: Imagable 4T1 model for the study of late stage breast cancer. BMC Cancer 8: 228, 2008 .
44. DuPre' SA and Hunter KW Jr: Murine mammary carcinoma 4T1 induces a leukemoid reaction with splenomegaly: Association with tumor-derived growth factors. Exp Mol Pathol 82: 12-24, 2007.

45. Liu H, Tabuchi T, Takemura A, Kasuga T, Motohashi G, Hiraishi K, Katano M, Nakada I, Ubukata $\mathrm{H}$ and Tabuchi T: The granulocyte/lymphocyte ratio as an independent predictor of tumour growth, metastasis and progression: Its clinical applications. Mol Med Rep 1: 699-704, 2008

46. Rochet NM, Markovic SN and Porrata LF: The role of complete blood cell count in prognosis-Watch this space! Oncol Hematol Rev 8: 76-82, 2012.

47. Benatar T, Cao MY, Lee Y, Li H, Feng N, Gu X, Lee V, Jin H, Wang M, Der S, et al: Virulizin induces production of IL-17E to enhance antitumor activity by recruitment of eosinophils into tumors. Cancer Immunol Immunother 57: 1757-1769, 2008.

48. Kousis PC, Henderson BW, Maier PG and Gollnick SO: Photodynamic therapy enhancement of antitumor immunity is regulated by neutrophils. Cancer Res 67: 10501-10510, 2007.

49. Eruslanov EB, Bhojnagarwala PS, Quatromoni JG, Stephen TL, Ranganathan A, Deshpande C, Akimova T, Vachani A, Litzky L, Hancock WW, et al: Tumor-associated neutrophils stimulate $\mathrm{T}$ cell responses in early-stage human lung cancer. J Clin Invest 124: 5466-5480, 2014

50. Mete S: Targeting tumor microenvironment by zoledronate as a novel therapeutic approach in cancer (dissertation). University of Zurich, Faculty of Science, Zurich, 2011.

51. Demers M, Krause DS, Schatzberg D, Martinod K, Voorhees JR, Fuchs TA, Scadden DT and Wagner DD: Cancers predispose neutrophils to release extracellular DNA traps that contribute to cancer-associated thrombosis. Proc Natl Acad Sci USA 109: 13076-13081, 2012

52. Schmidt H, Bastholt L, Geertsen P, Christensen IJ, Larsen S, Gehl $\mathbf{J}$ and von der Maase H: Elevated neutrophil and monocyte counts in peripheral blood are associated with poor survival in patients with metastatic melanoma: A prognostic model. Br J Cancer 93: 273-278, 2005

53. Atzpodien $\mathbf{J}$ and Reitz M: Peripheral blood neutrophils as independent immunologic predictor of response and long-term survival upon immunotherapy in metastatic renal-cell carcinoma. Cancer Biother Radiopharm 23: 129-134, 2008.

54. Coffelt SB, Kersten K, Doornebal CW, Weiden J, Vrijland K, Hau CS, Verstegen NJ, Ciampricotti M, Hawinkels LJ, Jonkers J, et al: IL-17-producing $\gamma \delta \mathrm{T}$ cells and neutrophils conspire to promote breast cancer metastasis. Nature 522: 345-348, 2015

55. Shimada H, Takiguchi N, Kainuma O, Soda H, Ikeda A, Cho A, Miyazaki A, Gunji H, Yamamoto H and Nagata M: High preoperative neutrophil-lymphocyte ratio predicts poor survival in patients with gastric cancer. Gastric Cancer 13: 170-176, 2010.

56. Shibutani M, Maeda K, Nagahara H, Noda E, Ohtani H, Nishiguchi Y and Hirakawa K: A high preoperative neutrophil-tolymphocyte ratio is associated with poor survival in patients with colorectal cancer. Anticancer Res 33: 3291-3294, 2013.

57. Chen J, Deng Q, Pan Y, He B, Ying H, Sun H, Liu X and Wang S: Prognostic value of neutrophil-to-lymphocyte ratio in breast cancer. FEBS Open Bio 5: 502-507, 2015.

58. Koh CH, Bhoo-Pathy N, Ng KL, Jabir RS, Tan GH, See MH, Jamaris S and Taib NA: Utility of pre-treatment neutrophillymphocyte ratio and platelet-lymphocyte ratio as prognostic factors in breast cancer. Br J Cancer 113: 150-158, 2015

59. Templeton AJ, McNamara MG, Šeruga B, Vera-Badillo FE, Aneja P, Ocaña A, Leibowitz-Amit R, Sonpavde G, Knox JJ, Tran B, et al: Prognostic role of neutrophil-to-lymphocyte ratio in solid tumors: A systematic review and meta-analysis. J Natl Cancer Inst 106: dju124, 2014.

60. Ueta E, Osaki T, Yoneda K, Yamamoto T and Umazume M: Influence of inductive chemoradiotherapy on salivary polymorphonuclear leukocyte (SPMN) functions in oral cancer. J Oral Pathol Med 23: 418-422, 1994

61. Baskic D, Arsenijevic NN and Acimovic LD: Monocyte phagocytic function in patients with breast cancer during therapy. Meeting abstracts, 23rd Congress of the International Association of Breast Cancer Research, 13-16 June, Dusseldorf, Germany. http://breast-cancer-research.com/content/3/S1

62. Reshma K, Bharathi B, Rao AV, Dinesh M and Vasudevan DM: Phagocytosis: A marker of decreased immune response in radiation treated oral cancers. Biomed Res 20: 75-77, 2009.

63. Cron J and Jansa P: Role of phagocytic cells in cancer. Folia Haematol Int Mag Klin Morphol Blutforsch 108: 481-527, 1981 . 
64. Karagöz B, Bilgi O, Alacacioğlu A, Ozgün A, Sayan O, Erikçi AA and Kandemir EG: Mean platelet volume increase after tamoxifen, but not after anastrazole in adjuvant therapy of breast cancer. Med Oncol 27: 199-202, 2010.

65. Taucher S, Salat A, Gnant M, Kwasny W, Mlineritsch B, Menzel RC, Schmid M, Smola MG, Stierer M, Tausch C, et al; Austrian Breast and Colorectal Cancer Study Group: Impact of pretreatment thrombocytosis on survival in primary breast cancer. Thromb Haemost 89: 1098-1106, 2003.

66. Brockmann MA, Giese A, Mueller K, Kaba FJ, Lohr F, Weiss C, Gottschalk S, Nolte I, Leppert J, Tuettenberg J, et al: Preoperative thrombocytosis predicts poor survival in patients with glioblastoma. Neuro Oncol 9: 335-342, 2007.

67. Lu CC, Chang KW, Chou FC, Cheng CY and Liu CJ: Association of pretreatment thrombocytosis with disease progression and survival in oral squamous cell carcinoma. Oral Oncol 43: 283-288, 2007.

68. Stravodimou A and Voutsadakis IA: Pretreatment thrombocytosis as a prognostic factor in metastatic breast cancer. Int $\mathrm{J}$ Breast Cancer 2013: 289563, 2013.

69. Digklia A and Voutsadakis IA: Thrombocytosis as a prognostic marker in stage III and IV serous ovarian cancer. Obstet Gynecol Sci 57: 457-463, 2014.

70. Gasic GJ, Gasic TB and Stewart CC: Antimetastatic effects associated with platelet reduction. Proc Natl Acad Sci USA 61: 46-52, 1968.

71. Li R, Ren M, Chen N, Luo M, Deng X, Xia J, Yu G, Liu J, He B, Zhang $\mathrm{X}$, et al: Presence of intratumoral platelets is associated with tumor vessel structure and metastasis. BMC Cancer 14: 167, 2014.

72. Mikami J, Kurokawa Y, Takahashi T, Miyazaki Y, Yamasaki M, Miyata H, Nakajima K, Takiguchi S, Mori M and Doki Y: Antitumor effect of antiplatelet agents in gastric cancer cells: An in vivo and in vitro study. Gastric Cancer 19: 817-826, 2016.

73. Stone RL, Nick AM, McNeish IA, Balkwill F, Han HD, Bottsford-Miller J, Rupairmoole R, Armaiz-Pena GN, Pecot CV, Coward $\mathrm{J}$, et al: Paraneoplastic thrombocytosis in ovarian cancer. N Engl J Med 366: 610-618, 2012.

74. Sitia G, Aiolfi R, Di Lucia P, Mainetti M, Fiocchi A, Mingozzi F, Esposito A, Ruggeri ZM, Chisari FV, Iannacone M, et al: Antiplatelet therapy prevents hepatocellular carcinoma and improves survival in a mouse model of chronic hepatitis B. Proc Natl Acad Sci USA 109: E2165-E2172, 2012.

75. Rachidi S, Wallace K, Day TA, Alberg AJ and Li Z: Lower circulating platelet counts and antiplatelet therapy independently predict better outcomes in patients with head and neck squamous cell carcinoma. J Hematol Oncol 7: 65, 2014.
76. Adler HL, McCurdy MA, Kattan MW, Timme TL, Scardino PT and Thompson TC: Elevated levels of circulating interleukin-6 and transforming growth factor-betal in patients with metastatic prostatic carcinoma. J Urol 161: 182-187, 1999.

77. Petanidis S, Anestakis D, Argyraki M, Hadzopoulou-Cladaras M and Salifoglou A: Differential expression of IL-17, 22 and 23 in the progression of colorectal cancer in patients with K-ras mutation: Ras signal inhibition and crosstalk with GM-CSF and IFN- $\gamma$. PLoS One 8: e73616, 2013.

78. Liu M, Jin X, He X, Pan L, Zhang X and Zhao Y: Macrophages support splenic erythropoiesis in 4T1 tumor-bearing mice. PLoS One 10: e0121921, 2015.

79. Yilmaz M, Cimilli G, Saritemur M, Demircan F, Isaoglu U, Kisaoglu A and Emet M: Diagnostic accuracy of neutrophil/lymphocyte ratio, red cell distribution width and platelet distribution width in ovarian torsion. J Obstet Gynaecol 36: 218-222, 2016.

80. Kritchevsky SB and Kritchevsky D: Serum cholesterol and cancer risk: An epidemiologic perspective. Annu Rev Nutr 12: 391-416, 1992.

81. Hussein MA and Boshra SA: Antitumor and structure antioxidant activity relationship of colchicine on Ehrlich ascites carcinoma (EAC) in female mice. Int J Drug Deliv 5: 430-437, 2013.

82. Furberg AS, Jasienska G, Bjurstam N, Torjesen PA, Emaus A, Lipson SF, Ellison PT and Thune I: Metabolic and hormonal profiles: HDL cholesterol as a plausible biomarker of breast cancer risk. The Norwegian EBBA Study. Cancer Epidemiol Biomarkers Prev 14: 33-40, 2005.

83. Jafri H, Alsheikh-Ali AA and Karas RH: Baseline and on-treatment high-density lipoprotein cholesterol and the risk of cancer in randomized controlled trials of lipid-altering therapy. J Am Coll Cardiol 55: 2846-2854, 2010.

84. Touvier M, Fassier P, His M, Norat T, Chan DS, Blacher J, Hercberg S, Galan P, Druesne-Pecollo N and Latino-Martel P: Cholesterol and breast cancer risk: A systematic review and meta-analysis of prospective studies. Br J Nutr 114: 347-357, 2015.

85. Robinson JG: Low high-density lipoprotein cholesterol and chronic disease risk marker or causal? J Am Coll Cardiol 55: 2855-2857, 2010.

86. Ravichandran P, Elangovan V and Govindasamy S: Chemopreventive effect of quercetin in sarcoma-180-bearing mice. J Clin Biochem Nutr 22: 149-154, 1997. 